\title{
Role of Preoperative Skin Traction in Reducing Pain in Patient with Hip Fracture
}

\author{
Saeed Taj Din ${ }^{1}$, Bilal Raza², Farrukh Sarfraz ${ }^{3}$ \\ 1,2Department of Orthopedics, Azra Naheed Medical College / Chaudhry Muhammad Akram Teaching \& Research Hospital, Lahore-Pakistan, ${ }^{3}$ Department of Medical Education, Azra \\ Naheed Medical College / Chaudhry Muhammad Akram Teaching \& Research Hospital, Lahore-Pakistan
}

\begin{abstract}
Background: Hip Fracture including neck of femur and trochanteric fractures are very common in young and old age. These types of injuries in young age are mainly due to malnutrition, tumor, physical inactivity and athletic participation causing high energy trauma. In old age it is mainly due to osteoporotic bones especially in females. Objective: To compare mean pain score in patients with hip fractures treated with and without skin traction prior to surgical intervention. Study Design: Randomized control trial. Settings: Orthopedics department, Chaudhry Muhammad Akram Teaching \& Research Hospital, affiliated with Azra Naheed Medical College Lahore-Pakistan. Duration: 2 Years from 01-01-2017 to 31-12-2019. Methodology: Data of all the hip fractures presenting in Orthopedic emergency was collected. This includes fracture neck of femur and trochanteric fractures. Results: Application of skin traction did not result in improvement of pain score significantly. $15.0 \%$ of respondents were in the age groups of $25-40$ years, $38.0 \%$ patients were between $41-60$ years of age and $47 \%$ patients more than 61 years of age. $69.0 \%$ were female patients and $32.0 \%$ were male patients. Mean preoperative visual analogue score (VAS) score of all patients 2.3900 (out of 10 score). Mean Preoperative visual VAS score of patients (with skin traction) 2.5400. In other group (without skin traction), mean preoperative VAS score 2.2400. Conclusion: Preoperative skin traction in hip fractures of adult patient should not be considered mandatory in reducing pain and hence it is not useful.
\end{abstract}

Keywords: Proximal Hip Fracture, Skin Traction, Pain reliever.

Corresponding Author

Submitted for Publication: 14-05-2020

Dr. Farrukh Sarfraz, Assistant Professor, Department of Medical Education, Azra Naheed Medical College, Lahore-Pakistan.

Email: drsaeed2003@yahoo.com

Citation: Din ST, Raza B, Sarfraz F. Role of Preoperative Skin Traction in Reducing Pain in Patient with Hip Fracture. APMC 2020;14(3):237-9.

\section{DOI: $10.29054 / A P M C / 2020.935$}

\section{INTRODUCTION}

Proximal femur fractures under the heading of hip fracture that include fracture neck of femur and trochanteric fractures. They are common in female patient with ratio 3:1. Risk factors include, osteoporosis ${ }^{1}$ impaired neurology, malnutrition, impaired vision, tumor and physical inactivity. ${ }^{2}$ Sub trochanteric fractures, also included in proximal femur fracture with by model distribution pattern that is common in patients with 20 to 40 years of age and then in patients with more than 60 years of age. Prognosis of hip fractures depend on age of the patient. ${ }^{2}$

Proximal femoral fractures usually need surgical intervention. It is being observed that elderly patients need medical evaluation preoperatively which may result in some delay in surgery. These fractures are not common in young patients but preoperative preparation sometime take longer as fracture usually takes place due to high energy trauma that may need soft tissue healing. ${ }^{3}$ Thus aim to decrease preoperative pain in patient with hip fracture in all patients preoperatively. skin traction is being applied with the belief that immobilizing fractured limb with it will reduce pain, conservative treatment by skin traction is still in practice in some hip fractures patients due to some specific reasons. ${ }^{3}$

According to result of some studies there was no advantage of skin traction in controlling pain of fracture and hence analgesic required. ${ }^{4}$ But skins traction is used in routine as department policy in many centers taking it as part of initial management of fracture in relieving pain, possibly to create the impression that active measures are being taken for pain and fracture control. Magnitude of pain is measured by using visual analogue scoring (VSA) system. Scoring ranges from 0 to 10 , where 0 will be taken as no pain and 10 for severe pain. ${ }^{5}$

In a study done by Saygi et ${ }^{1,6}$ al pain reduction among patients with intertrochanteric femur fracture with skin traction and without skin traction was compared. The pain assessed on visual analogue scoring (VAS) at 12 hours preoperatively and score was found $3.63( \pm 0.84)$ and $3.04( \pm 0.76)$ respectively.

The rationale of this study is to asses mean pain score by using skin traction and without it in hip fracture patients 12 hours before undergoing surgical interventions. Application of skin traction consider to be pain relieving but on other hand there are other hazards like pressure sores, local allergic reaction, blisters secondary to mechanical shearing forces. Different studies done on skin traction showed no role in pain reduction. ${ }^{2}$

In a study done by handoll 7,8 et al different studies for comparison of pre-operative traction versus no traction had been evaluated. In this evaluation handoll ${ }^{9}$ et al had mean $( \pm$ $2.4)$ in traction group and $3.4( \pm 2.1)$ in no traction group and Guay $\mathrm{J}$ et al had a mean score of $4.62( \pm 2.42)$ in traction group and $4.68( \pm 2.89)$ in no traction group. ${ }^{10}$

We conducted this study in the tertiary care hospitals to asses mean pain score after application of skin traction and without it in patients with hip fractures before undergoing surgical 
interventions, in order to suggest guidelines in for use of skin traction as departmental protocol. ${ }^{11,12,13}$

\section{METHODOLOGY}

Study Design: Randomized control trial.

Settings: Orthopedic department, Chaudhry Muhammad Akram Teaching \& Research Hospital Lahore affiliated with Azra Naheed Medical College Lahore Pakistan.

Duration: The time period of study was 2 Years (Ist January 2017 to 31st December 2018).

Sample Technique: Non random sampling.

Sample Size: One hundred patients were included which were divided in two groups with 50 patients in each.
Inclusion Criteria: All adults patient of any gender with fracture neck of femur were included.

Exclusion Criteria: No patient was included without fracture neck of femur.

Data Collection and Analysis: One hundred patients were included which were divided in two groups with 50 patients in each. Group A with skin traction and Group B patients were managed without any skin traction prior surgical intervention. Pain score assessed by using Visual analogue pain (VAS) scale and presented in the form of table. Mean preoperative pain score comparison was calculated by using independent t-test sampling. $P$ value less than 0.05 was considered as significant.

Table 1: Independent Samples Test

\begin{tabular}{|c|c|c|c|c|c|c|c|c|c|}
\hline \multirow{3}{*}{$\begin{array}{c}\text { Preoperative VAS } \\
\text { score }\end{array}$} & \multicolumn{2}{|c|}{$\begin{array}{c}\text { Levene's Test } \\
\text { for Equality of } \\
\text { Variances }\end{array}$} & \multicolumn{7}{|c|}{ T-test for Equality of Means } \\
\hline & \multirow[b]{2}{*}{$\mathbf{F}$} & \multirow[b]{2}{*}{ Sig. } & \multirow[b]{2}{*}{$\mathrm{T}$} & \multirow[b]{2}{*}{ Df } & \multirow[b]{2}{*}{$\begin{array}{l}\text { Sig. (2- } \\
\text { tailed) }\end{array}$} & \multirow[b]{2}{*}{$\begin{array}{c}\text { Mean } \\
\text { Difference }\end{array}$} & \multirow[b]{2}{*}{$\begin{array}{l}\text { Std. Error } \\
\text { Difference }\end{array}$} & \multicolumn{2}{|c|}{$\begin{array}{l}95 \% \text { Confidence Interva } \\
\text { of the Difference }\end{array}$} \\
\hline & & & & & & & & Lower & Upper \\
\hline $\begin{array}{l}\text { Equal variances } \\
\text { assumed }\end{array}$ & .040 & .842 & 1.709 & 98 & .091 & .30000 & .17559 & -.04846 & .64846 \\
\hline $\begin{array}{l}\text { Equal variances } \\
\text { not assumed }\end{array}$ & & & 1.709 & 97.235 & .091 & .30000 & .17559 & -.04849 & .64849 \\
\hline
\end{tabular}

\section{RESULTS}

Our study included 100 cases of fractures in adults. Mean age was 39 years SD \pm 13.67 with minimum age 26 years and maximum age 74 years. Mean age of patients in Group A (with traction) $46.98 \mathrm{SD} \pm 14.80$ with minimum age 27 years and maximum age 75 years and in Group B (without skin traction) $45.80 \mathrm{SD} \pm 12.56$ with minimum age 26 years and maximum age 74 years. Fifteen percent of respondents were in the age groups of $25-40$ years, $38.0 \%$ patients were between $41-60$ years of age and $47 \%$ patients more than 61 years of age. $69.0 \%$ were female patients and $32.0 \%$ were male patients. $44.0 \%$ of fractures were of neck of femur, $33.0 \%$ were pertrochantaric and $23.0 \%$ were subtrochanteric fractures.

Mean preoperative VAS score of all patients 2.3900 SD .88643 with minimum VAS 1 and maximum VAS 5. Mean preoperative VAS scores of group A (with skin traction) $2.5400 \mathrm{SD} \pm 0.83812$ with minimum VAS 1 and maximum VAS 4. In group $B$ (without skin traction), mean preoperative VAS score is $2.2400 \mathrm{SD} \pm$ 0.91607 with minimum VAS 1 and maximum VAS 5.

Independent $t$ test was used to calculate mean VAS score of two groups and found no significant difference. $(t=1.709 p>.091)$.

\section{DISCUSSION}

Proximal femoral fractures having a big contribution to musculoskeletal trauma burden at tertiary care centers are among the most common injuries that could be dealt only by surgical management. Preoperative Pain management is considered important in two groups. As per traditional treatment, traction is believed to reduce pain, that's the reason skin traction usually applied in these patients. ${ }^{14}$

Different studies showed insignificant efficacy of traction but no single study showed either added advantage of neither skin traction nor its placebo effect. For placebo effect skin traction was applied without weight being attached to it. ${ }^{15}$

In our study Mean Preoperative VAS score of group A (with skin traction) was $2.5400 \mathrm{SD} \pm 0.83812$ with minimum VAS was 1 and maximum VAS was 4 . In group $B$ (without skin traction), mean preoperative VAS score was $2.2400 \mathrm{SD} \pm 0.91607$ with minimum VAS was 1 and maximum VAS was 5 . Independent $t$ test showed insignificant difference in mean VAS scores of two groups. $(t=1.709 p>$.091).

\section{CONCLUSION}

The conclusion of the study is:

- There is no difference in preoperative pain reduction among hip fracture patients with putting on skin traction or without putting skin traction.

- Routine use of skin traction in hip fracture patients is not useful in reducing pain preoperatively.

\section{LIMITATIONS}

This study was conducted at one center and total numbers of patients are limited as per our local capability.

We recommend extending this study to multiple centers and more researchers may be involved to formulate guide lines 
regarding usefulness for skin traction in reducing pain in proximal femoral fractures.

\section{SUGGESTIONS / RECOMMENDATIONS}

Our study was conducted in one hospital. Further validity of the study needs that it should be conducted in multicenter. In this study skin traction was not compared with placement of Branbohler's frame in patients with hip fractures.

\section{CONFLICT OF INTEREST / DISCLOSURE}

Independent study founded and performed with in the Pakistani health system. Approval by the relevant institutional ethical review board, written informed consent by participants. All data were received, checked and analyzed statistically and results were obtained.

\section{ACKNOWLEDGEMENTS}

I wish to express my gratitude to Prof. Dr. Muhammad Akbar Chaudhry, for his continuous support, guidance and constructive feedback for the completion of my research project. I am very thankful to Prof. Dr. Muhammad Zahid for support and guided me by critical appraisal from the beginning to the end.

I am also very thankful to my family especially my family who spare me for the completion of my research.

I also pay my regard to all those who supported me for the completion of my research project.

\section{REFERENCES}

1. Manafi Rasi A, Amoozadeh F, Khani S, Kamrani Rad A, Sazegar A. The Effect of Skin Traction on Preoperative Pain and Need for Analgesics in Patients with Intertrochanteric Fractures: A Randomized Clinical Trial. Arch Trauma Res. 2015;4(2):e12039.

2. Hussain Z, Raza S, Momin A, Ali N. Comparison of mean pain score by applying with and Without skin traction in patients with hip fracture. PJMHS. 2015;9:185-8.

3. Shaikh $A M$, Shahwani MB, Ishaq M. Hip fracture. Professional Med J. 2018;25(01):30-3.

4. Course NR. The elderly with a fractured hip-analgesia. 15th North West Anaesthetic Refresher Course. 2019;61(2):9.

5. Matullo KS, Gangavalli A, Nwachuku C. Review of Lower Extremity Traction in Current Orthopaedic Trauma. J Am Acad Orthop Surg. 2016;24(9):600-6.

6. Kenanidis E, Potoupnis ME, Kakoulidis $P$, Leonidou A, Sakellariou GT, Sayegh FE, Tsiridis E. Management of glucocorticoid-induced osteoporosis: clinical data in relation to disease demographics, bone mineral density and fracture risk. Expert Opin Drug Saf. 2015;14(7):1035-53.

7. Handoll HH, Keding A, Corbacho B, Brealey SD, Hewitt C, Rangan A. Five-year follow-up results of the PROFHER trial comparing operative and non-operative treatment of adults with a displaced fracture of the proximal humerus. Bone Joint $\mathrm{J}$. 2017;99-B(3):383-92.

8. Avenell A, Smith TO, Curtain JP, Mak JC, Myint PK. Nutritional supplementation for hip fracture aftercare in older people. Cochrane Database Syst Rev. 2016;11(11):CD001880.

9. Hall M. Clinical Practice: Critical Inquiry. 2017;2(1)534-47.
10. Guay J, Parker MJ, Gajendragadkar PR, Kopp S. Anaesthesia for hip fracture surgery in adults. Cochrane Database Syst Rev. 2016;2(2):CD000521.

11. Järvinen TL, Michaëlsson $K$, Jokihaara J, Collins GS, Perry TL, Mintzes B, Musini V, Erviti J, Gorricho J, Wright JM, Sievänen H. Overdiagnosis of bone fragility in the quest to prevent hip fracture. BMJ. 2015;350:h2088.

12. Pincus D, Ravi B, Wasserstein D, Huang A, Paterson JM, Nathens AB, Kreder HJ, Jenkinson RJ, Wodchis WP. Association Between Wait Time and 30-Day Mortality in Adults Undergoing Hip Fracture Surgery. JAMA. 2017;318(20):1994-2003.

13. Homma Y, Baba T, Ozaki Y, Watari T, Kobayashi H, Ochi H, Matsumoto M, Kaneko K. In total hip arthroplasty via the direct anterior approach, a dual-mobility cup prevents dislocation as effectively in hip fracture as in osteoarthritis. Int Orthop. 2017;41(3):491-7.

14. Yamamoto $Y$, Turkiewicz A, Wingstrand $H$, Englund M. Fragility Fractures in Patients with Rheumatoid Arthritis and Osteoarthritis Compared with the General Population. J Rheumatol. 2015;42(11):2055-8.

15. Qin CD, Helfrich MM, Fitz DW, Hardt KD, Beal MD, Manning DW. The Lawrence D. Dorr Surgical Techniques \& Technologies Award: Differences in Postoperative Outcomes Between Total Hip Arthroplasty for Fracture vs Osteoarthritis. J Arthroplasty. 2017;32(9):3-7.

\section{AUTHORSHIP CONTRIBUTION}

\begin{tabular}{|l|l|}
\hline Dr. Saeed Taj Din & \\
Assistant Professor of Orthopedics, Azra & \\
Naheed Medical College / Chaudhry & Manuscript writing \\
Muhammad Akram Teaching \& Research & \\
Hospital, Lahore Pakistan & \\
\hline Dr. Bilal Raza & \\
Associate Professor of Orthopedics, Azra & Data Collection \\
Naheed Medical College / Chaudhry & \\
Muhammad Akram Teaching \& Research & \\
Hospital, Lahore Pakistan & \\
\hline Dr. Farrukh Sarfraz & \\
Assistant Professor of Medical Education, & Critical Review \\
Azra Naheed Medical College / Chaudhry & \\
Muhammad Akram Teaching \& Research & \\
Hospital, Lahore Pakistan & \\
\hline
\end{tabular}

